\title{
Strategi Organisasi Informal Menjaga Persistensi Pasar Tradisional di Kecamatan Padang Barat
}

\author{
RINEL FITLAYENI ${ }^{1}$, MARLENI², ELVAWATI ${ }^{3}$ \\ 1,2,3 Program Studi Pendidikan Sosiologi, STKIP PGRI Sumatera Barat \\ remail: ${ }^{123}$ rin3l_inzaghi@yahoo.co.id
}

\begin{abstract}
The focus ofthis study is to examine the Strategy Informa Organizations Maintaining Persistence of Traditional Markets. This is due tothe marketis animportant institution in economic institutions. In addition, the market serves to bring together the economic actors. The market also serves as an economicmeans of providing a barometer of the economy in the area of income generation. This study used a qualitative approach with descriptive type. Informants in this study is determined by means of intentional (purposive). Data collection techniquesin this studyis the observation, collection of documents (writings) and in-dept interview. From the results ofthe resilience oftraditional market research can not be separated from the role ofthe actor, especially traders. Through informal traders by establishing Organiasai. The strategiesthey doamong other things, (a) streng then social networks among the sellers; (b) increase social networks with consumer; (c) increase solidarity.
\end{abstract}

Keywords: strategy, organization, persistence, tradisional market

\begin{abstract}
Abstrak. Fokus penelitian ini ingin mengkaji Strategi Organisasi Informal Menjaga Persistensi Pasar Tradisional. Hal ini disebabkan pasar merupakan suatu lembaga yang penting dalam institusi ekonomi. Selain itu, pasar berfungsi untuk mempertemukan para pelaku ekonomi. Pasar juga berfungsi sebagai suatu sarana ekonomi yang menjadi tolak ukur dalam peningkatan pendapatan ekonomi di daerah. Penelitian ini menggunakan pendekatan kualitatif dengan tipe penelitian deskriptif. Informan dalam penelitian ini ditentukan dengan cara disengaja (purposive). Teknik pengumpulan data dalam penelitian ini adalah observasi,studi dokumen dan wawancara mendalam. Dari hasil penelitian ketahanan pasar tradisional tidak terlepas dari peran aktor terutama pedagang. Melalui pedagang dengan membentuk organiasai informal. Adapun strategi yang mereka lakukan antara lain, (a) memperkuat jaringan sosial sesama pedagang, (b) meningkatkan jaringan sosial dengan pembeli, (c) meningkatkan solidaritas.
\end{abstract}

Kata Kunci: strategi, organisasi, persistensi, pasar Tradisional

\section{Pendahuluan}

Ide dasar dari sebuah pasar adalah agar segala proses transaksi, pertukaran barang \& jasa berlangsung dengan biaya transaksi yang rendah dan efektif, adil dan secara sosial melibatkan banyak pelaku yang berkepentingan, secara ekonomi bermanfaat bagi kesejahteraan masyarakat maupun secara finansial menguntungkan bagi semua pelaku di dalamnya, baik penjual, pembeli, maupun pelaku pendukung lainnya.

Pasar merupakan pranata yang mengatur komunikasi dan interaksi antara para penjual dan pembeli yang bertujuan untuk mengadakan transaksi pertukaran benda-benda, jasa, uang, dan tempat hasil transaksi dapat disampaikan pada waktu yang akan datang berdasarkan harga yang telah ditetapkan. Sedangkan menurut Blair area pasar adalah wilayah dimana suatu pasar dapat dijual (dalam Ansofino 2014: 83). Oleh sebab itu, pasar merupakan salah satu lembaga yang penting dalam institusi ekonomi. Untuk melakukan transaksi ekonomi, aktivitas ekonomi di Pasar tradisional cenderung melihat hubungan aspek-aspek ekonomis dan nonekonomis dari kehidupan pasar yang memengaruhi proses-proses ekonomi. Aktivitas-aktivitas ekonomi seperti produksi,

Received: 2 November 2014, Revision:20 Juni 2015, Accepted: 22 Juni 2015

Print ISSN: 0215-8175; Online ISSN: 2303-2499. Copyright@2015. Published by Pusat Penerbitan Universitas (P2U) LPPM Unisba Terakreditasi SK Kemendikbud, No.040/P/2014, berlaku 18-02-2014 s.d 18-02-2019 
distribusi perdagangan dan konsumsi, nantinya akan disusun ke dalam perananperanan dan kolektivitas; dengan nilai-nilai apa ia dilegitimasi; dan dengan norma-norma serta sanksi apa ia diatur (Smelser, 1987: 23). Dengan kata lain, persoalan ekonomi juga perlu memertimbangkan institusi-institusi masyarakat lainnya yang dapat memperlancar atau menghambat aktivitas-aktivitas ekonomi yang dilakukan oleh aktor-aktor ekonomi.

Di pasar tradisional interaksi antara pedagang dan pembeli tidak sekadar menerima uang dan pembeli menerima barang, namun akan dapat menciptakan hubungan sosial yang terjalin dalam proses jualbeli tersebut. Proses tawar menawar di pasar tradisional dapat menjadi interaksi sosial yang berkelanjutan karena pedagang dan pembeli akan saling mengenal. Ketika pedagang menjelaskan karakter barang yang dijual, pembeli akan merasa puas menukarkan barang dengan sejumlah uang yang akan diberikan kepada pedagang. Terkait dengan hal tersebut di atas, pasar tidak saja sebagai istitusi ekonomi, tetapi juga sebagai institusi sosial yang dapat memenuhi kebutuhan sosial para aktor yang terlibat di pasar tersebut.

Kebutuhan sosial akan dapat terpenuhi ketika seseoarang merasa puas dengan apa yang didapatkan dari proses yang dilakukannya. Berdasarkan pendekatan sosiologi ekonomi, Leksono (2009: 31) menyatakan bahwa pasar tradisional adalah modus interaksi sosial dan budaya, serta sebagai salah satu institusi pelayanan publik. Sebagai sebuah bentuk pelayanan publik, pasar tradisional dituntut untuk dapat memberikan pelayanan yang baik dan memuaskan penggunanya. Terkait dengan pelayanan tersebut, kendala utama yang dihadapi pasar tradisional yaitu masalah pengelolaan yang kurang profesional. Mulai dari masalah kebersihan seperti lingkungan yang becek, sampah menggunung di pojok pasar, kemacetan dan minimnya sarana kebersihan di pasar (Adri, dalam Kompas, 2006).

Pascagempa di Sumatera Barat pada tahun 2009, Pasar Raya Padang yang merupakan pasar induk di Kota Padang mengalami kerusakan yang sangat berat dan membutuhkan renovasi serta revitalisasi. Kondisi ini akan menambah ketidaknyamanan pasar tradisional, baik oleh pedagang maupun pembeli. Akibatnya, pedagang kaki lima semakin menjamur diruas-ruas jalan utama Pasar Raya Padang, kemacetan menjadi- jadi dan merampas hak pejalan kaki dan pengguna kendaraan. Hal ini menyebabkan semakin semerawutnya Pasar Raya Padang. Kondisi tersebut juga memicu munculnya pasar bayangan di berbagai jalan dalam Kota Padang yang menawarkan berbagai jenis barang dagangan. Kondisi tersebut tentunya akan menimbulkan masalah terhadap persistensi pasar tradisional, khususnya di Kecamatan padang Barat.

Berdasarkan latar belakang di atas, maka yang menjadi tujuan penelitian adalah mendeskripsikan lebih lanjut strategi organisasi informal menjaga persistensi pasar tradisional di Kecamatan Padang Barat

Damsar dalam bukunya Sosiologi Ekonomi (2010: 15) mendefinisikan pasar sebagai salah satu lembaga yang paling penting dalam institusi ekonomi, yang menggerakkan dinamika kehidupan ekonomi. Sedangkan menurut Alfred Marshal dalam bukunya Damsar Sosiologi menyatakan pasar adalah sebagai suatu mekanisme dalam penciptaan harga. Sedangkan, menurut Nugroho (Zusmelia dkk, 2012: 126) aktivitas transaksi yang terjadi di pasar saat sekarang telah memperlihatkan terjadinya transaksi dalam bentuk rasionalisasi dalam kehidupan ekonomi yang menempatkan semangat costbenefit calculation sebagai landasan utama dalam berperilaku.

Pasar tradisional adalah pasar yang dalam pelaksanaannya bersifat tradisional dan ditandai dengan pembeli serta penjual yang bertemu secara langsung. Proses jualbeli biasanya melalui proses tawar menawar harga, dan harga yang diberikan untuk suatu barang bukan merupakan harga tetap, dalam arti lain masih dapat ditawar. Ciri Ciri Pasar Tradisional adalah (1) Proses jual-beli melalui tawar menawar harga; (2) Barang yang disediakan umumnya barang keperluan dapur dan rumah tangga; (3) Harga yang relatif lebih murah; dan (4) Area yang terbuka dan tidak ber-AC.

Pasar tradisional juga identik dengan menyuguhkan suasana lalu lalang pengunjung mencari barang yang lebih murah harganya dibanding dengan pedagang yang lain, pembeli pun dapat duduk membaur di antara pedagang tanpa ada pembatas, sehingga semua dapat serba hidup, saling memberi dan menerima sejajar pada posisi yang sama derajat. Proses jual beli terjadi secara interaktif, harga bukan hal yang pasti, keuntungan bukan menjadi tujuan utama, tetapi kebersamaan menyertainya. 
Komunikasi dan interaksi sosial terjalin dengan sendirinya, suasana keakraban antara penjual dan pembeli terwujud.

Menurut Belshaw (1981: 21) mengurai tentang pasar tradisional dalam bukunya Tradisional Exchange and Modern Market, yaitu pembahasan tentang meretas struktur ekonomi dari ekonomi tradisional ke ekonomi modern. Dalam pembahasannya ada empat pokok masalah yang menjadi fokusnya, yaitu nilai tukar, pemasaran di kalangan petani dengan menggunakan uang, pendekatan tekanan tekanan dalam ekonomi, dan kondisi pembaharuan dalam pemasaran.

Selain itu, dalam pembahasan masalah pasar tradisional ini, Belshaw juga membahas tentang tata susunan serta kaitan sosial yang ada di dalamnya. Seperti tentang bagaimana mekanisme koordinasinya, pandangan mengenai nilai-nilai kehidupan, sistem alokasi dan distribusi, kewiraswastaan, dan pengaruh kekuasaan pemerintah setempat.

Selanjutnya, Belshaw mengemukakan tentang ciri khas yang membedakan sistem perdagangan pasar tradisional dari perdagangan lain, yaitu adanya sistem harga luncur (sliding price system). Sistem harga luncur yang berupa tawar menawar, karena tidak adanya kepastian harga maka akan menciptakan persaingan, bukan antara penjual dengan penjual seperti pada lazimnya tetapi antara pembeli dengan penjual.

Dengan kelangkaan barang akan memengaruhi posisi penjual dan pembeli. Pengetahuan mengenai kekuatan harga yang sedang berlangsung di pasar akan diteruskan dari mulut ke mulut sehingga tersebarke seluruh masyarakat. Menurut Abdullah (1999 : 32), pasar tradisional selama ini selalu identik dengan biaya rendahnya, hampir semua barang yang dijual di pasar tradisional mempunyai kualitas yang sama dengan barang yang dijual di mal-mal, namun, jika dibandingkan dalam segi harga, pasar tradisional dalam menawarkan harga kepada pembeli jauh lebih murah dari pada harga yang ditawarkan oleh pasar modern.

Penelitian tentang pasar sebagai institusi ekonomi terpenting sudah banyak dilakukan. Salah satunya Zusmelia (2017, 167), dalam penelitiannya persistensi pasar nagari dari waktu ke waktu disebabkan keterlekatan (1) tindakan ekonomi aktor dalam jaringan sosial personal yang sedang berlangsung; (2) tindakan ekonomi dengan sistem sosial budaya masyarakat.
Pendekatan untuk melakukan penelitian menggunakan pendekatan kualitatif dengan tipe penelitian deskriptif, tujuan mendeskripsikan strategi organisasi informal untuk menjaga persistensi pasar tradisional. Sedangkan lokasi penelitian ini dilakukan di Kota Padang Sumatera Barat. Dipilihnya lokasi ini karena Kota Padang adalah karena Ibu Kota Propinsi Sumatera Barat, pusat pemerintahan, dan pusat pendidikan.

Fokus penelitian ini hanya akan mengambil lokasi di pasar tradisional di Padang Barat yaitu Pasar Raya. Berikut ini beberapa alasan pemilihan Padang Barat sebagai lokasi penelitian: (1) Pasar Raya sebagai pasar induk terletak di Padang Barat; (2) Pasar Raya Padang yang mengalami kerusakan berat pasca gempa Sumbar tahun 2009 terletak di Padang Barat; (3) Wilayah Padang Barat merupakan pusat kota hingga saat sekarang ini; (4) Tingkat kepadatan penduduk serta heterogenitas penduduk yang tinggi di Kecamatan Padang Barat.

Untuk pemilihan informan dengan menggunakan cara disengaja (purposive) artinya para informan dicari berdasarkan kriteria-kriteria tertentu yang telah ditetapkan oleh peneliti, dan peneliti mengetahui identitas orang-orang yang pantas menjadi informan dan keberadaan mereka diketahui oleh peneliti (Afrizal, 2008: 43).

Dalam penelitian ini yang menjadi informannya adalah ikatan pedagang yang terbentuk di pasar raya seperti ikatan pedagang ayam, ikatan pedagang buah, ikatan pedagang ikan, ikatan pedagang daging. Sedangkan teknik pengumpulan informan dengan cara pengumpulan dokumen( tulisantulisan) terkait berita di media, notulennotulen rapat, dan laporan-laporan untuk mencari informasi yan diperlukan. Dalam penelitian ini penulis juga menggunakan pengumpulan dokumen untuk mendapatkan data-data tertulis yang gunanya sebagai data pendukung untuk penelitiannya.

Selanjutnya, dengan cara observasi, yaitu alat pengumpulan data yang dilakukan dengan mengamati dan mencatatat secara sistimatik gejala-gejala yang diselidiki. Observasi dilakukan dengan cara tidak terlibat secara langsung. Artinya, peneliti mengamati bentuk-bentuk interaksi yang terjadi antara penjual dengan pembeli yang terjadi di pasar raya, salah satunya ketika terjadi transaksi jual beli.

Teknik pengumpulan data selanjutnya 
adalah wawancara mendalam. wawancara mendalam yaitu sebuah wawancara tidak berstruktur antara pewawancara dengan informan yang dilakukan berulang-ulang kali dengan pertanyaan yang berbeda dan mengkasifikasi informasi yang sudah dapat sebelumnya. Dalam hal ini peneliti tetap memakai pedoman wawancara tujuannya supaya peneliti tidak lari dari pokok permasalah yang diinginkan sesuai dengan tujuan penelitian. Dalam melakukan penelitian penulis memberi tahu kepada informan kegunaan dari penelitian ini. Proses wawancara yang dilakukan ketika informan tidak sibuk melayani pembeli.

\section{Strategi Organisasi Informal Men- jaga Persistensi Pasar Tradisional.}

Pasar sebagai salah satu bentuk kelembagaan ekonomi memiliki peran dalam menciptakan stabilitas kehidupan masyarakat. Khususnya pasar tradisional, yang mampu menampung usaha dari masyarakat menengah ke bawah. Keberadaan pasar tradisional mulai terancam sejak terjadinya gempa besar pada tanggal 30 September 2009 lalu. Akibatnya, banyak sarana dan prasana yang ada disana yang rusak parah. Kondisi tentu saja mengancam keberadaan pasar tradisional terutama pedagang karena turunnya daya beli masyarakat, terutama di pasar raya. Keadaan ini semakin terancam dengan keberadaan pasar modern yang mulai menjamur di tengah-tengah masyarakat yang juga menjadi pilihan bagi pembeli untuk belanja di sana.

Menjamurnya pasar modern juga menandakan bahwa industrialisasi dan neoliberalisme sudah memengaruhi masyarakat. Konsekuensinya, perubahanperubahan sosial ekonomi dalam masyarakat tidak bisa dihindari, terutama eksistensi pasar tradisional yang dianggap sebagai local genius yang keberadaannya paling dekat dengan kehidupan masyarakat. Industrialisme melalui pembangunan pasar modern tentu saja membawa dampak terhadap pedagang terutama pedagang pasar tradisional seperti turunnya omset penjualan dan berkurangnya pembeli. Oleh sebab itu, ketahanan atau keberadaan pasar tradisional di tengah pertumbuhan pasar modern yang semakin menjamur harus di counter oleh berbagai pihak terutama pedagang maupun pemerintah melalui berbagai macam strategi untuk menjaga persistensi keberadaan pasar tradisional.

\section{Membuat Jaringan Sosial Sesama Pedagang}

Salah satu bentuk strategi hubungan yang dilakukan antara pedagang di pasar tradisional melalui jaringan sosial. Jaringan sosial adalah ikatan antar simpul (orang atau kelompok) yang dihubungkan dengan media (hubungan sosial). Salah satunya melalui organisasi informal. Hal ini dilakukan para pedagang untuk menjaga persistensi pasar tradisional, pedagang Pasar Raya Kota Padang. Adapun strategi informal yang mereka bentuk seperti seperti ikatan pedagang buah, ikatan pedagang ikan, ikatan pedagang $P \& D$, ikatan pedagang ayam, ikatan pedagang daging. Meskipun organisasi ini tidak memiliki mekanisme pertemuan yang rutin tetapi hubungan secara personal terjalin cukup erat karena setiap hari bersama-sama bekerja sebagai pedagang.

Pada dasarnya, keterlibatan pedagang dalam organisasi yang terdapat dipasar sangat diperlukan. Sebab, organisasi yang dibentuk bukan tanpa ada alasan sama sekali, tetapi juga bertujuan untuk mengayomi dan melindungi para pedagang baik secara hukum maupun sosial ekonomi. Perlindungan secara hukum pada dasarnya melindungi pedagang dari kebijakan pemerintah yang dianggap merugikan mereka serta kebijakan yang dikeluarkan pemerintah secara sepihak.

Sejalan dengan pendapat Anderson dan Woodrow (Endrizal, 2009: 31) bahwa strategi bertahan hidup selain mengandalkan fisik untuk berusaha lebih keras memenuhi kebutuhan ekonomi, juga srategi secara material yang dimaknai dengan mendapatkan modal usaha dalam berdagang. Selanjutnya, yang tidak kalah penting strategi melalui organisasi sosial adalah dengan cara mengandalkan organisasi-organisasi dan komunitas-komunitas yang ada. Dalam kasus pedagang pasar tradisonal, maka organisasi sosial yang dimaksud adalah organisasi yang di bentuk oleh para pedagang-pedagang pasar tradisional, organisasi sosial ini dibentuk bertujuan sebagai wadah sekaligus menjadi aspirasi bagi para pedagang dalam mengurai permasalahan-permasalahan yang terjadi di tengah pedagang pasar tradisional.

Artinya, melalui organisasi yang dibentuk oleh pedagang, melalui ikatan pedagang tersebut untuk mempererat hubungan diantara pedagang, mendapatkan informasi-informasi yang berhubungan dengan pasar dan barang dagangan serta 
kepentingan kelompok. Ikatan pedagang yang dibentuk juga bertujuan agar tercipta interaksi dan komunikasi yang baik didalam kelompok. Salah satu bentuknya adanya penentuan harga yang sama sesama pedagang sehingga tercipta integrasi yang bagus sesama pedagang. Dengan interaksi yang baik sesama pedagang, tentu akan menciptakan hubungan yang baik sehingga antara pedagang dengan pedagang hubungan terjalin dengan baik, pedagang dan pembeli juga. Dampak dari terciptanya hubungan sosial tersebut adalah munculnya kenyaman pembeli dalam berbelanja di pasar sehingga pasar raya tetap digemari oleh pembeli. Hal ini dituturkan oleh AK (Anggota Ikatan Pedagang Buah):

"untuk bisa bertahan berdagang dipasar raya, saya ikut ikatan pedagang buah yang ada disini. Alasan saya ikut ikatan pedagang untuk meningkatkan hubungan sosial antara pedagan, meningkatkan keamanan, bisa bertahan berdagang dan juga untuk menciptakan kenyamanan kepada pembeli".

Penuturan Ak juga didukung pernyataan dari RJ (Sekretaris Ikatan Pedagang Ayam):

\begin{abstract}
Pasar raya ini masih bisa eksis, menurut saya tidak terlepas dari ikatan-ikatan pedagang yang ada disini. Ikatan pedagang yang ada bertujuan untuk mengakomodir pedagang-pedagang pasar supaya tetap bisa berdagang dipasar raya kemudian juga untuk menyamakan harga barang yang bertujuan menciptakan kesenangan dan kenyamanan kepada pembeli sehingga pembeli senang berbelanja disini dari pada di pasar modern. Selain itu ikatan ini juga dibentuk untuk mempertahankan pasar raya tetap diminati oleh pembeli.
\end{abstract}

Berdasarkan paparan informan di atas ikatan yang dibentuk oleh pedagang di Pasar Raya Padang bertujuan untuk menjaga supaya pelanggan ataupun pembeli nyaman dan pedagang tetap bisa berdagang ataupun bertahan menjadi pedagang karena tujuan dari ikatan pedagang selain untuk meningkatkan hubungan sosial antarsesama pedagang juga untuk menjaga persistensi pasar supaya tetap eksis pasca gempa dan dari pasar modern yang sudah mulai menjamur di kota Padang.

Pada dasarnya hubungan yang terjalin antara sesama pedagang melalui organisasi lebih didasarkan kepada rasa senasib dan sepenanggungan. Di mana hubungan yang terbangun di dasarkan atas rasa persaudaraan yang tinggi. Artinya hubungan yang terjadi diantara mereka bisa bersifat ekspresif atau emosional, tetapi juga bersifat instrumental. Hal ini disebabkan karena pedagang tidak selalu memperlihatkan hak dan kewajiban semata, akan tetapi dipengaruhi oleh situasi pertukaran waktu da sumber daya yang mempunyai nilai sosial ekonomi bagi mereka. Menurut Weber, tindakan ekonomi selalu melibatkan makna. Weber mengklasifikasikan tipe-tipe tindaka sosial antara lain (Ritzer, 2010: 40):

(1) Rasionalitas Instrumental, meliputi pertimbangan dan pilihan yang sadar yang berhubungan dengan tujuan tindakan dan menilai alat yang dipergunakan untuk mencapai tujuan; (2) Rasionalitas berorientasi nilai, meliputi pertimbangan dan pilihan yang sadar yang berhubungan dengan tujuan dan menilai alat yang dipergunakan untuk mencapai tujuan tetapi lebih berorientasi terhadap nilai, dimana nilai bersifat absolut; (3) Tindakan afektif, tindakan yang ditandai oleh dominasi perasaan atau emosi tanpa refleksi intelektual atau perencanaan yang sadar; (4) Tindakan tradisional, merupakan tindakan yang dilakukan karena kebiasaan.

\section{Meningkatkan Jaringan Sosial dengan Pembeli}

Selain membuat ikatan pedagang untuk menjaga ketahanan pasar tradisonal dari maraknya pasar modern saat ini, pedagang juga mejalin hubungan yang baik kepada konsumen (pembeli) seperti bersikap ramah, santun, dan komunikasi yang baik. Adapun tujuan pedagang adalah agar pembeli tetap berbelanja di pasar tradisional. Karena bagaimanapun tanpa pembeli pasar tradisional tidak akan bisa eksis walaupun pedagang yang ada di dalamnya kompak dengan persatuan yang kuat. Pembeli merupakan orang aktor yang tak kalah penting dari pedagang, tanpa pembeli pedagang tidak akan bisa bertahan dipasar. Oleh sebab itu, antara pedagang dengan pembeli juga terjalin hubungan yang baik. Seperti yang diungkapkan oleh HA:

Supaya saya tetap bisa berjualan di sini dan jualan saya laris, saya menjalin hubungan yang baik dengan pembeli. Pembeli tersebut menjadi langganan saya karena mereka merasa nyaman berbelanja dengan saya. Bentuk hubungan tersebut tidak hanya sampai di situ saja, klau ada pelangan saya yang menikah dan saya diundangnya maka saya akan pergi ketempat undangan tersebut atau memberikan amplop kepada pelagan saya kalau saya tidak sempat hadi sebagai wujud kedekatan hubungan dan menarik pelangan untuk tetap membeli kepada saya.

Hal yang sama juga disampaikan oleh AR (pembeli):

Saya senang beberbelanja di pasar tradisional. Selain masih segar-segar, pedagangnnya juga ramah tamah, hubungan kalu kita sudah jadi pelangan tidak dilihat dari pedagang dan pembeli saja lagi tapi hubungannya sudah lebih seperti kalau uang kurang boleh utang dulu, 
minggu depan dibayar. Ini yang membuat saya tetap berbelanja diPasar Raya Padang dari pada di mall

Menjalin hubungan yang baik dengan pembeli melalui peningkatan pelayanan yang dilakukan oleh pedagang adalah dengan cara memberikan keringanan kepada pembeli dengan membolehkan utang atau dengan ambil di muka tinggal di belakang (utang dengan tempo). Dengan cara ini, pelanggan masih terikat dengan hutang, sehingga diharapkan pembeli akan kembali lagi untuk belanja. Sebenarnya, sisa kekurangan uang yang diberikan merupakan salah satu cara untuk memertahankan keberadaan pembeli, dan yang lebih mendalam adalah adanya rasa kebersamaan dengan memberikan keringanan pembayaran, sehingga adanya rasa menolong kepada pembeli, jadi bukan mencari untung semata tapi adanya rasa saling membutuhkan.

Pembayaran yang dilakukan bisa tempo. Pembayaran tempo ini biasanya dikenakan bagi pembeli yang jumlahnya relatif besar dan sudah saling kenal. Waktu yang diberikannya pun berbeda-beda tergantung kesepakatan yang dilakukan dengan pembeli tersebut. Adapun tujuannya peningkatan kualitas pelayanan oleh pedagang lebih kepada perhatian dari pedagang yang merasa telah terbantu dengan ikut sertanya pembeli dalam usaha dagangnya. Walaupun pembeli dan penjual merupakan hukum alam bahwa kalau ada penjual pasti ada pembeli, disini tidak saja dihitung secara ekonomis tapi lebih dalam hubungan sosial budaya yang kuat, karena bagaimana pun modal yang ada secara ekonomis relatif kecil, jadi akan lebih kuat apabila ditopang oleh modal sosial dalam bentuk kekeluargaan dan kepercayaan dalam masyarakat. Keberadaan pasar tradisional akan tetap eksis selama masih ada segmen masyarakat yang berdaya beli rendah (rakyat miskin), karena pasar tradisional adalah salah satu pengakses barang kebutuhan pokok dengan harga yang murah dan terjangka. Artinya jaringan sosial yang dimaksudkan di sini lebih kepada jaringan sosial informal yang dilakukan oleh para pedagang Pasar Raya Padang. Jaringan sosial (social network) yang dimaksud dalam penelitian ini adalah proses pengelompokan yang terdiri atas sejumlah orang yang masing-masing mempunyai identitas sendiri dan dihubungkan melalui hubungan sosial yang ada, sehingga melalui hubungan-hubungan tersebut mereka dapat dikelompokkan menjadi satu kesatuan sosial (Suparlan, 1982:35). Ikatan-ikatan sosial yang terjalin antar individu dan kelompok saling bekerjasama untuk mencapai tujuan tertentu sehingga hubungan-hubungan tersebut tidak dapat berdiri sendiri maupun dipisahkan satu dengan yang lainnya

Dalam konteks ini, para pedagang Pasar Raya sebagai induk dari pasar tradisional yang ada di kota Padang memiliki kemampuan untuk memanfaatkan, memertahankan dan mengembangkan jaringan sosial untuk menjalankan aktivitas ekonomi (jual beli) dengan berbagai pihak yang terlibat, salah satunya dengan pembeli dan pelanggan. Pedagang yang memiliki jaringan sosial dilandasi oleh ikatan yang kuat dan memiliki motivasi lebih besar untuk saling membantu dan lebih cepat untuk saling memberikan bantuan dalam mengatasi masalah kesulitan dan tekanan hidup. Oleh karena itu jaringan sosial yang dibentuk oleh pedagang Pasar Raya Inpres Padang dapat memberikan pengaruh positif bagi keberlangsungan bisnisnya serta kebertahanan pasar raya sebagai pasar tradisional.

Hal senada juga ditemukan pada pasar tradisional lainnya, baik Pasar Tanah Kongsi maupun Pasar Purus Pagi. Salah satu jaringan sosial yang terbentuk di sana adalah antara pedagang dengan pembeli. Jaringan sosial tersebut tidak sekadar hubungan jual beli sesaat, tetapi hubungan yang terjalin berlangsung dalam jangka waktu panjang. Salah satu bentuk hubungan jangka panjang yang terjalin antarkedua aktor ini adalah proses langganan. Di sini, pedagang berusaha untuk memertahankan pembeli sebagai pelanggan tetap dengan memberikan informasi, sehingga tidak jarang ditemukan pedagang yang meminta nomor handphone pembeli. Bagi pedagang maupun pembeli, tindakan mereka dalam hubungan ini samasama memiliki nilai yang dapat menjadi acuan mereka dalam mencapai tujuan.

Selain memberikan keringanan kepada pembeli dalam bentuk jatuh tempo untuk pembayaran barang, pedagang juga memberikan kualitas sempurna baik dari segi barang maupun dalam pelayanan. Ini merupakan salah satu strategi untuk memertahankan persistensi pasar raya. Apalagi pascagempa, di mana banyak bangunan permanen yang rata dengan tanah. Konsekuensinya para pedagang harus berjualan di kios-kios darurat yang dibuat sementara oleh pemerintah. Kondisi kios tersebut jika sudah hujan memungkinkan untuk becek, kotor dan tergenang air. Hal ini tentu saja mengurangi minat pembeli 
untuk datang ke pasar tradional sehingga untuk mengatasi masalah ini akan dilakukan berbagai cara oleh pedagang untuk tetap menjalankan bisnisnya serta kebertahanan pasar raya sendiri. Kualitas barang dagangan sangat diutamakan oleh pedagang pasar tradisional dengan membeli ke petani langsung bahan dagangannya sehingga mutunya masih bagus karena baru dipetik ataupun diambil oleh petani maupun dengan mempertahankan kondisi barang dagangannya seperti ikan masih dalam keadaan hidup ketika mau dijual sehingga para pembeli diperbolehkan memilih mana yang mereka suka.

Selain itu, jaringan sosial juga ikut berperan dalam menentukan harga. Artinya, pedagang juga bisa memberikan harga yang murah kepada pembeli jika pembeli ada yang memiliki hubungan keluarga dan hubungan persahabatan dengan penjual. Begitu juga dengan kualitas pelayanan juga diperhatikan para pedagang dengan cara bersikap ramah, sopan, menghargai pembeli, memberikan kepuasan terhadap pembeli, dan kerapihan. Karena moto mereka bahwa "pembeli adalah raja." Hal senada juga diungkapkan pembeli RK.

Sejak dulu saya lebih senang belanja di sini, meskipun kondisi pasar raya setelah gempa banyak berubah. Hal ini disebabkan saya punya banyak langganan dari berbagai macam pedagang. Di sini selain barang dagangan masih termasuk baru dan bisa kita pilih, pelayanan yang diberikan juga ramah dan sopan.

Di sini dapat dilihat bahwa transaksi ekonomi antara kelompok dengan perorangan yang terjalin untuk mendapatkan sesuatu yang menjadi kebutuhannya berupa barang atau jasa secara kontinuitas. Hal ini sesuai dengan yang diungkapkan oleh Belshaw (1981: 7) bahwa perdagangan di dalamnya terdapat tukar menukar, menerobos seluruh bangunan sosial dan dapat dipandang sebagai tali pengikat masyarakat. Oleh karena itu, aktivitas perdagangan dapat melahirkan bentuk-bentuk interaksi dari hubungan yang akrab di antara orang-orang yang terlibat di antaranya.

Apalagi dalam era pascakrisis ekonomi ini, keberadaan pasar tradisional semakin banyak dibutuhkan, karena jumlah rakyat miskin yang semakin bertambah, tapi hal ini, harus diimbangi dengan keadilan dan pemerataan pendapatan. Selama ini pemerintah hanya mengedepankan sektor ekonomi besar serta orientasi kebijakan yang lebih mementingkan pertumbuhan belaka.
Artinya, keberadaan pasar tradisional bisa bertahan pada saat sekarang ini, karena pedagang maupun pembeli saling menjaga hubungan sosial yang baik serta menjalin hubungan lebih dari pada hubungan antara seorang pedagang dan pembeli. Hal ini disebabkan adanya pemaknaan pedagang dan pembeli dalam menafsirkan keuntungankeuntungan yang mereka dapatkan ketika mereka berbelanja maupun berdagang di pasar tradisional, ini yang mengakibatkan sampai pada saat sekarang pasar tradisional masih digemari oleh masyarakat baik kelas bawah, menengah, maupun kelas atas.

\section{Meningkatkan Solidaritas}

Untuk menjaga kebertahanan pasar tradisional pascagempa dan dari gempuran pasar modern yang sudah menjamur di Kota Padang, khususnya Kecamatan Padang Barat, strategi yang digunakan oleh organisasi informal adalah meningkatkan hubungan yang baik dan solidaritas yang tinggi antarpedagang melalui julo-julo, koperasi pedagang, sumbangan untuk meninggal dan menikah.

Seperti julo-julo, sebenarnya julojulo dapat dijadikan jembatan atau media untuk mampu bertahan dalam berdagang di pasar tradisional di antara berbagai macam gempuran pasar modern saat ini untuk bisa bertahan untuk menafkahi anggota keluarga mereka. Bahkan, menurut Nugroho (Endrizal, 2009: 126), arisan atau julo-julo merupakan struktur mediasi sebagai sarana pemberdayaan individu agar mereka tidak mengalami alienasi dalam menghadapi mega structures, serta mampu mengatasi problema kemiskinan dan ketidakberdayaan, di mana individu merasa at home dalam masyarakat, sehingga kebijakan publik akan lebih bermakna bagi individu. Julo-julo atau arisan yang dilakukan oleh pedagang pasar tradisional tentu saja merupakan salah satu bentuk usaha yang dilakukan pedagang pasar tradisional untuk tetap bertahan.

Julo-julo yang dilaksanakan sesuai dengan kesepakatan seperti 1 kali 15 hari ( $1 \times 2$ minggu) yang dipegang oleh orang dianggap dipercayai oleh pedagang. Julo-julo yang dilakukan oleh para pedagang dibentuk berdasarkan jenis dagangan dan tempatnya. Julo-julo, selain berbentuk uang, juga berbentuk barang seperti kebutuhan pokok yang akan diberikan pada saat menggelar hajatan seperti pesta perkawinan.

"Julo-julo" berupa barang seperti 
barang untuk memenuhi kebutuhan pokok seperti beras, daging, cabe dan kebutuhan lainnya. Mereka menyumbangkan sejumlah bantuan tersebut dengan kesepakatan yang telah ditentukan. Tradisi ini dilakukan oleh pedagang dengan harapan pada saat pedagang lain mengadakan pesta perkawinan juga memberikan barang kebutuhan yang sama di kemudian hari. Menurut salah satu informan dalam penelitian ini, besar kecilnya sumbangan berbentuk materi ini bergantung pada kedekatan hubungannya dengan pedagang tersebut.

Hasil penelitian juga menunjukkan di Pasar Purus Pagi dan Pasar Tanah Kongsi bahwa pedagang membentuk arisan yang dikenal dengan istilah "julo-julo". Julojulo muncul diakibatkan karena lembaga formal yang mendukung keberlangsungan usaha pedagang. Pada dasarnya, julo-julo merupakan salah satu bentuk kerjasama pertukaran (resiprositas) antara beberapa orang yang bersepakat pada suatu kelompok atau komunitas dalam bentuk uang atau barang kebutuhan pokok. Arisan ini diketuai oleh satu orang yang dipercayai oleh para pedagang lain untuk bisa menjalankan kegiatan ini. Bentuk kerjasama ini bergiliran menerima uang arisan di antara para anggota komunitas atau kelompok berdasarkan nomor urut yang disepakati secara bersama-sama.

Julo-julo yang diikuti oleh pedagang ini biasanya yang sekolompok barang dagangannya, seperti julo-julo antara pedagang buah, tetapi ada juga yang lintas dagangan. Uang yang diterima juga bermacam-macam seperti ada yang sekali terima sampai Rp.10.000.000,- Uang hasil julo-julo ini dipergunakan bermacam-macam, ada untuk modal usaha, simpanan maupun memenuhi kebutuhan hidup sehari-hari.

\footnotetext{
Seperti yang diungkapkan oleh pedagang (AZ)
}

Saya ikut julo-julo sudah 5 tahun ini, banyak sekali manfaat yang diterima jika ikut julojulo. Salah satunya sebagai simpanan jika terjadi apa-apa nanti. Selain itu bisa digunakan untuk memenuhi kebutuhan hidup sehari-hari. Apalagi jika kita berdagang belum selalu tentu menghasilkan pendapatan lebih setiap harinya.

Pada dasarnya, julo-julo merupakan lembaga yang bersifat informal yang dibentuk oleh para pedagang itu sendiri yang dibuat berdasarkan ikatan dari jenis barang dagangan dan tempat berdagang. Menurut Dalton (1959:219) organisasi informal merupakan ikatan-ikatan yang spontan dan fleksibel di antara anggota-anggota yang dituntun oleh perasaan-perasaan dan kepentingan pribadi yang dapat dipertahankan oleh kegiatan formal. Kegiatan ini sangat membantu para pedagang untuk memertahankan kelangsungan hidupnya.

Dari penjelasan di atas, maka dapat ditarik kesimpulan bahwa kegiatan "julo-julo" ini secara tidak langsung mereka melekat pada eksistensi hubungan-hubungannya, baik secara horizontal maupun vertikal di kelompok arisan pedagang. Kondisi ini tidak terlepas dai perasaan yang sama yaitu senasib dan sepenanggungan di antara mereka yang diperlihatkan dalam bentuk rasa toleransi, tanggung jawab, tolong menolong, dan dapat membantu di saat mengalami kesulitan. Dengan adanya ikatan tersebut mereka berusaha untuk menjaga dan memertahankan hubungan baik dengan sesama individu di dalam kelompok arisan tersebut.

Pada dasarnya,kegiatan julo-julo yang dilakukan oleh para pedagang juga merupakan jembatan untuk menambah modal tambahan melalui tabungan secara kolektif diantara mereka. Selain tabungan secara kolektif, dalam julo-julo tersebut juga dibahas tentang bagaimana memajukan pasar tradisional seperti bagaimana menarik pembeli supaya barang dagangannya tetap diminati

Tabel 1

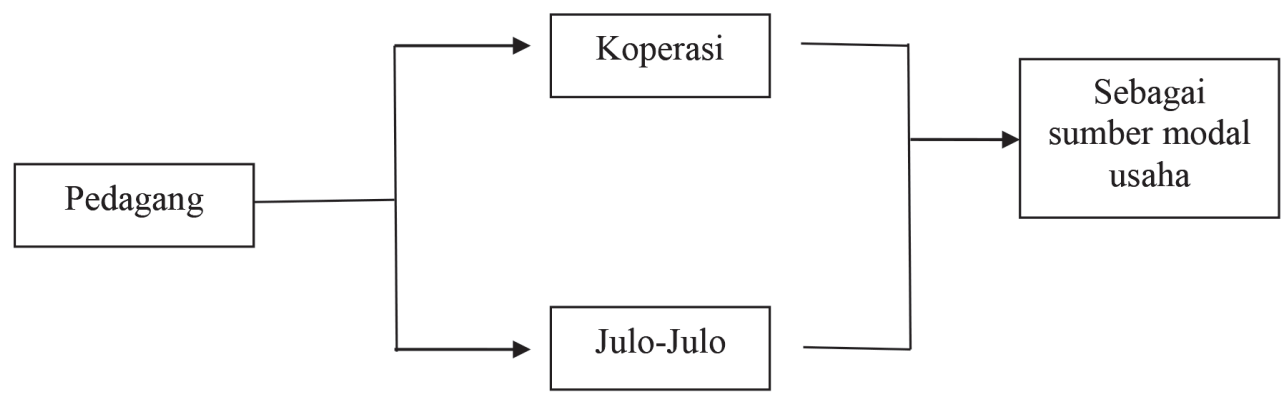


oleh konsumen, bagaimana konsumen tetap berbelanja ke pasar tradisional dan tidak beralih ke pasar modern, membahas tentang persamaan harga serta membantu pemerintah supaya pasar tradisional (Pasar Raya Padang) tetap diminati oleh konsumen khusus pembeli.

\section{Hal ini didukung oleh pernyataan YI}

strategi kami sebagai seorang pedagang supaya tetap bisa bertahan berjualan disini adalah adanya solidaritas yang tinggi antar kami pedagang ibaratnyasakik sanang basoamo, kalau diantara kami ada yang kekurangan modal akan dibantu dengan uang koperasi yang kami bentuk atau dengan uang julo-julo. Sistem julo-julo kami adalah siapa yang butuh dia yang dikasih duluan. Itu yang membuat kami tetap bertahan berdagang di pasar Raya ini.

Berdasarkan pernyataan YL dengan adanya solidaritas yang tinggi sesama pedagang membuat mereka tetap bertahan berdagang di pasar raya, secara tidak langsung dengan bertahannya pedagang akan menjaga ketahanan pasar tradisonal dari berbagai ancaman.

Hal yang sama juga disampaikan oleh Mc, bahwa solidaritas antarpedagang ditingkatkan dengan cara menghargai dan menghormati serta membantu masalahmasalah yang dihadapi oleh pedagang lain. Seperti kalau ada anggota keluarga pedagang yang pesta maka ikatan pedagang akan mengirimkan ucapan selamat, kalau ada yang meninggal akan pergi melayat. Hal ini bertujuan kalau hubungan di antara pedagang tidak hanya sebagai pedagang saja tetapi sudah lebih.

Selain kegiatan julo-julo yang dilakukan oleh sesama pedagang, koperasi juga merupakan salah satu sarana untuk membangun solidaritas diantara sesama mereka. Pada dasarnya lembaga ini didirikan untuk melayani anggotanya dalam memenuhi kebutuhan pokoknya yaitu para pedagang itu sendiri. Mereka dapat menyimpan dan meminjam uang sebagai modal yang diikuti dengan kewajibannya sebagai anggota dengan menyerahkan simpanan wajib dan simpanan pokok ke koperasi.

Pada dasarnya keikutsertaaan koperasi tanpa ada paksaan artinya siapa pedagang yang hanya mau ikut saja. Untuk Pasar Purus Pagi, keikut sertaan pedagang dalam koperasi ini tertuang pada SK Menkop 8 PKN No. 04/ BH/KDK - /310/TU/X/1998 untuk simpanan pokok anggota Rp 100.000,- / orang, sedangkan simpanan wajibnya sebanyak Rp.
20.000,-. Untuk peminjaman masing-masing anggota maximal Rp 30.000.000,-. Kegiatan koperasi yang dilakukan oleh pedagang juga sangat menguntungkan mereka.

\section{Salah satu informan (SS) menyatakan \\ Disini selain julo-julo, juga ada koperasi. Saya salah satu anggota koperasi di Pasar Purus Pagi. Saya kemarena baru meminjam sebanyak Rp. 25.000.000, - untuk perhelatan perkawinan anak saya. Tetapi banyak juga anggota yang meminjam untuk membeli barang lain seperti motor.}

Keikutsertaan pedagang dalam berbagai bentuk kegiatan baik seperti julo-julo maupun koperasi merupakan salah satu strategi bagi mereka untuk menjaga persistensi pasar tradisional. Hal ini dapat dilihat pada Tabel 1.

Pada dasarnya, keikutsertaaan pedagang dalam berbagai kegiatan untuk meningkatkan solidaritas memunyai banyak manfaat antara lain, secara ekonomis untuk menggalang modal bagi kelompok pedagang pasar tradisional. Sedangkan secara sosial budaya meningkatkan tali kekerabatan antaranggota kelompok dan secara politik bisa juga sebagai penyalur aspirasi anggota kelompoknya.

\section{Simpulan dan Saran}

Terdapat beberapa strategi yang dilakukan organisasi informal untuk memertahankan persistensi pasar tradisional antara lain: (a) memperkuat jaringan sosial antar pedagang, dengan membentuk ikatan pedagang untuk mengayomi dan melindungi para pedagang, baik secara hukum maupun sosial ekonomi; (b) meningkatkan jaringan sosial dengan pembeli seperti bersikap bersikap ramah, santun, dan komunikasi yang baik, agar pembeli tetap berbelaja di pasar tradsional; (c) meningkatkan solidaritas melalui kegiatan julo-julo maupun koperasi sebagai jembatan atau media untuk mampu bertahan dalam berdagang di antara berbagai macam gempuran pasar modern.

Memertimbangkan begitu pentingnya keberadaan pasar tradisional untuk menopang perekonomian kelas menengah ke bawah serta ada beberapa strategi yang dilakukan oleh para aktor salah satunya kepada pemerintah segera membenahi kondisi pasar tradisional sehingga aktivitas jual beli berjalan lancar terutama bagi pedagang karena terjadinya penurunan omset mereka pasca gempa.

\section{Daftar Pustaka}

Afrizal.(2008)."Pengantar Metode Kualitatif" 
RINEL FITLAYENI. DKK. Strategi Organisasi Informal Menjaga Persistensi Pasar Tradisional di Kecamatan Padang ...

Padang: Laboratorium Sosiologi Fisip Unand.

Abdullah. Irwan. (1999). Pedagang Kecil di Jatinom, Studi Tentang Tipe danKehidupan Harian Pedagang di Pedesaan Jawa Tengah. Yogyakarta: P3PKUGM

Ansofino. (2014). Penentuan Lokasi Pasar Induk dan Pasar Satelit di Kabupaten Solok Selatan, Vol 30, No. 1, pp 83.

Belswaw, Cyril. S.(1981).Tukar Menukar Tradisional Dan Pasar Modern. Jakarta: Gramedia

Damsar. (2010). Pengantar Sosiologi Ekonomi Jakarta: Kencana Prenada Media Group

Endrizal. (2009). Strategi Pedagang Pasar Tradisional Menghadapi Persaingan Dengan Pasar Modern (Penelitian di
Daerah Bukitting Sumatera Barat). Yogyakarta: UGM

Leksono. S.(2009). Runtuhnya Modal Sosial Pasar Tradisional. CV. Citra. Malang

Narbuko, Cholid \& Abu Achmadi. (2002). Metodologi Penelitian. Jakarta: Bumi Aksara.

Zusmelia, (2007). "Katahanan (Persistensi) Pasar Nagari Minangkabau, Kasus Pasar Kayu Manis (Cassiavera di Kabupaten Tanah Datar dan Agam Sumatera Barat). "IPB. Bogor

Zusmelia, dkk. (2012). Model Pengembangan Enterprneurship dalam Pemberdayaan Ekonomi Rumah Tangga di Minangkabau, Vol 28, No. 2, pp. 126. 